\title{
Ewa Kula, Naukowa, literacka i artystyczna twórczość nauczycieli rzqdowych szkól średnich Królestwa Polskiego w latach 1833-1862, Wydawnictwo Aka- demii Świętokrzyskiej, Kielce 2006, ss. 245
}

Ewa Kula jest adiunktem w Zakładzie Historii Wychowania i Organizacji Szkolnictwa Akademii Świętokrzyskiej w Kielcach. Do tej pory opublikowała kilkadziesiąt artykułów naukowych, odnoszących się do problematyki historii oświaty i szkolnictwa w XIX i XX w. Uczestniczy także w badaniach dotyczących nauczycieli szkół średnich Królestwa Polskiego, prowadzonych przez prof. dra hab. Adama Massalskiego.

Wyrazem zainteresowań badawczych Ewy Kuli jest jej praca pt. Naukowa, literacka $i$ artystyczna twórczość nauczycieli rzqdowych szkót średnich Królestwa Polskiego w latach 1833-1862, opublikowana w 2006 r., nakładem Wydawnictwa Akademii Świętokrzyskiej im. Jana Kochanowskiego. Stanowi ona studium monograficzne, będące - jak podała we „Wstępie” Autorka - próbą całościowego ujęcia problemu twórczości nauczycieli rządowych męskich szkół średnich w Królestwie Polskim. Za datę początkową rozpatrywanego okresu Autorka uznała rok 1833. Wyjaśniła tę decyzję przyjęciem nowej ustawy szkolnej dotyczącej zmian w zakresie szkolnictwa średniego w Królestwie Polskim. Za końcową datę uznała natomiast rok 1862, wtedy bowiem wprowadzona została w życie „Ustawa o wychowaniu publicznym w Królestwie Polskim”, również reorganizująca w znacznym stopniu system szkolny. Zamierzeniem publikacji było ukazanie wkładu nauczycieli w rozwój polskiej nauki oraz ustalenie ich miejsca w obszarze europejskich osiągnięć naukowych. Autorka stwierdziła, iż celem jej pracy nie jest „,analiza poszczególnych dzieł, ale zwrócenie uwagi na ich jakość [...], a takźe pokazanie zasięgu ich oddziaływania"1. Skupiła uwage na pięciu głównych zagadnieniach: 1. Twórczości nauczycieli w zakresie nauk ścisłych i technicznych; 2 . Działalności nauczycieli w dziedzinie biologii i nauk o ziemi, 3. Twórczości nauczycieli w zakresie nauk humanistycznych, społecznych i teologicznych; 4. Działalności nauczycieli w dziedzinie literackiej; 5. Twórczości artystycznej nauczycieli.

Autorka podała, że: „Konkretne ustalenia zawarte na kartach niniejszej monografii dotyczą dorobku nauczycieli pod względem ilościowym i jakościowym w dziedzinie badań naukowych, popularnonaukowych, przyczynkarskich oraz twórczości literackiej i artystycznej"2. Wyszła od określenia liczby oraz rodzaju wydawanych przez nauczycieli prac. W tym celu wykorzystała liczne opracowania monograficzne i bibliograficzne, encyklopedie i słowniki, źródła drukowane, pamiętniki i wspomnienia, czasopisma naukowe, społeczno-kulturalne i fachowe, drukowane publikacje nauczycieli szkół średnich oraz źródła archiwalne. Te ostatnie w większości zostały zgromadzone w Rosyjskim Archiwum Historycznym w Petersburgu, a uzupełnione materiałami pochodzącymi z Archiwum Państwowego w Łodzi, Kielcach, Radomiu, Płocku i Lublinie. Korzystała ponadto z rękopisów Biblioteki Uniwersytetu Warszawskiego oraz Biblioteki Jagiellońskiej.

\footnotetext{
${ }^{1}$ E. Kula, Naukowa, literacka i artystyczna twórczość nauczycieli rzqdowych szkót średnich Królestwa Polskiego w latach 1833-1862, Wydawnictwo Akademii Świętokrzyskiej, Kielce 2006, s. 13.

${ }^{2}$ Ibidem, s. 11.
} 
Na rozprawę złożyło się sześć rozdziałów. Pierwszy z nich nosi tytuł „Sytuacja nauczycieli szkół średnich rządowych Królestwa Polskiego w świetle polityki oświatowej caratu w latach 1833-1862" (s.17-28). Autorka zwróciła w nim m.in. uwagę na problem stopniowego obniżania poziomu polskiego szkolnictwa, spowodowanego zamknięciem Uniwersytetu Warszawskiego oraz wszystkich wyższych i średnich szkół w Królestwie Polskim, a także weryfikacją nauczycieli w zależności od ich postawy politycznej wobec państwa rosyjskiego. Podała również, jakie ograniczenia w sferze polskiej oświaty wprowadzały kolejne ustawy szkolne. Omówiła rodzaje rządowych szkół średnich oraz programy ich nauczania, a także wskazała na zmiany w zakresie ich organizacji i funkcjonowania. Zwróciła ponadto uwagę na system represji stosowany wobec polskich nauczycieli oraz na ich sytuację ekonomiczną.

Kolejne pięć rozdziałów rozprawy odnosi się do twórczości naukowej, literackiej i artystycznej nauczycieli. Rozdział drugi pt. „Twórczość nauczycieli w zakresie nauk ścisłych i technicznych" (s. 29-79) podejmuje problematykę działalności nauczycieli w dziedzinie matematyki, fizyki, astronomii, chemii i nauk technicznych. Autorka wskazała na ilościowy i jakościowy aspekt tego dorobku. Podała istotne fakty z życia oraz dokonała charakterystyki twórczości wybranych przedstawicieli poszczególnych dyscyplin; wymieniła i omówiła ich najważniejsze prace, wśród których znalazły się podręczniki, rozprawy, wykłady, thumaczenia, poradniki $i$ in. Najwięcej uwagi poświęciła dorobkowi matematyków, zwłaszcza A. Barcińskiego. Starała się również dowieść, iż „polityka zaborcy, utrudniająca i hamująca rozwój nauki polskiej, w mniejszym stopniu niż dotychczas sądzono, dotyczyła działalności naukowej nauczycieli" ${ }^{3}$.

Trzeci rozdział nosi tytuł „Twórczość nauczycieli w zakresie biologii i nauk o ziemi” (s. 81-109). W nim E. Kula dokonała omówienia prac z dziedziny biologii, nauk rolniczych, geografii i geologii. Bogatą charakterystykę dorobku poszczególnych nauczycieli (zwłaszcza biologów - zoologów i botaników, m.in. A. Wagi i J. Wagi) poprzedziła interesującym wprowadzeniem, dotyczącym organizacji nauczania przedmiotów przyrodniczych w Królestwie Polskim w latach 1833-1862. Zwróciła uwagę nie tylko na podręczniki, studia czy rozprawy autorstwa omawianych postaci, ale także na prace publicystyczne, biograficzne i bibliograficzne.

Rozdział czwarty i zarazem najbardziej obszerny, zatytułowany „Twórczosśc nauczycieli w zakresie nauk humanistycznych, społecznych i teologicznych" (s. 111-182), zawiera rozważania na temat prac z zakresu literaturoznawstwa, językoznawstwa, historii, języków obcych, prawa, religii oraz pedagogiki i nauczania początkowego. Autorka rozpoczęła rozdział od zaprezentowania informacji dotyczących organizacji kształcenia humanistycznego w omawianym okresie. Najszerzej omówiła twórczość nauczycieli języków obcych, którzy oprócz opracowywania podręczników, przygotowywali słowniki, a także pisali prace $\mathrm{z}$ dziedziny językoznawstwa (w tym dotyczące slawistyki). W zakresie językoznawstwa najbogatszy dorobek reprezentowany był przez A. Kudasiewicza. Zwróciła także uwagę na prace z zakresu historii, które - jak podała - miały „służyć walce o zachowanie kultury i ciągłości narodowej”․ Publikacje te dotyczyły przede wszy-

3 Ibidem, s. 79.

${ }^{4}$ Ibidem, s. 127. 
stkim historiografii antykwarycznej. Autorka podkreśliła, iż pomimo braku odpowiednich warunków (przede wszystkim właściwie zorganizowanych warsztatów pracy naukowej) autorzy ich przyczynili się do rozwoju nauk historycznych, przygotowując zarówno teksty źródłowe, jak i prowadząc badania na gruncie historii regionalnej. Swymi rozważaniami E. Kula objęła również twórczość nauczycielską w zakresie pedagogiki i nauczania początkowego, prezentując m.in. przykłady prac $\mathrm{z}$ dziedziny nauczania elementarnego (np. F. Zatorskiego), pracy wychowawczej (np. I. Boczylińskiego), reform szkolnictwa czy metodyki nauczania języka polskiego i historii. W zakresie działalności twórczej nauczycieli religii omówiła przede wszystkim prace teologiczne o charakterze naukowym, katechizmy oraz tzw. literaturę dewocyjną (m.in. ks. J. K. Mętlewicza i ks. J. Szpaderskiego). Najmniej uwagi poświęciła publikacjom z dziedziny prawa.

Piąty rozdział pracy pt. „Literacka twórczość nauczycieli” (s. 183-192) odnosi się do dorobku, na który złożyły się powieści o tematyce obyczajowej i historycznej, utwory dramatyczne i komediowe, wreszcie zbiory poezji. Autorka podała także liczne przykłady nauczycieli, którzy równocześnie prowadzili działalność naukową i literacką. W tej drugiej dziedzinie najbogatszy zbiór prac reprezentował pisarz i nauczyciel - J. Korzeniowski.

W rozdziale szóstym i zarazem ostatnim, zatytułowanym „Twórczość artystyczna nauczycieli" (s. 193-207), Autorka skoncentrowała się na dorobku w dziedzinie rysunku i kaligrafii (który objął przede wszystkim prace o tematyce historycznej i religijnej) oraz muzyki (na który złożyły się takie rodzaje utworów muzycznych, jak msze i pieśni religijne, a także koncerty fortepianowe, sonaty, uwertury, polonezy).

Zakończenie rozprawy stanowi rzeczowe podsumowanie podjętych przez Autorkę rozważań. Zdecydowanie zaprzeczono tu opinii, iż tylko nieliczni polscy nauczyciele omawianego okresu prowadzili prace badawcze i publikowali ich rezultaty.

Merytoryczna część niniejszego studium liczy 213 stron. Lekturę książki w znacznym stopniu ułatwia wykaz skrótów zawartych w przypisach, indeks nazwisk oraz przejrzyście zaplanowany spis źródeł i literatury. Swoistym urozmaiceniem są karty tytułowe wybranych publikacji kilku spośród prezentowanych nauczycieli.

Omawiana praca to cenne źródło wiedzy na temat zainteresowań i szeroko rozumianej działalności naukowej, literackiej i artystycznej nauczycieli rządowych męskich szkół średnich w Królestwie Polskim w latach 1833-1862. Można uznać ją za ważny wstęp do dalszych, bardziej szczegółowych badań nad poszczególnymi dziedzinami twórczości nauczycielskiej w okresie zaborów. Książkę tę polecam zarówno studentom pedagogiki, jak i nauczycielom oraz przyszłym adeptom tego zawodu. Warto bowiem nie tylko odwoływać się do najnowszych rozwiązań w zakresie edukacji, ale również do bogatego i cennego dorobku z jej przeszłości.

Tomasz Różański 